\title{
A study on the Length- Weight Relationship and Relative Condition Factor in Glossogobius giuris found in River Singla in the Karimganj district of Assam, India.
}

\author{
Satyajit Das* Masuk Ahmed Barbhuiya, Riazul Islam Barbhuiya and \\ Devashish Kar \\ Department of Life Science and Bioinformatics Assam University, Silchar
}

\begin{abstract}
An attempt had been made to develop a comparative relationship between the length and the weight of Glossogobius giuris and also the Relative condition factor (Kn) collected from the river Singla which is the inlet of one of the biggest wetland, Sone Beel in the Karimganj district of Assam. During the study period the value of exponent ' $n$ ' in the equation $W=c L^{n}$ was found to be 1.47 for the species. The computed ' $t$ ' value indicated that the ' $n$ ' value of the species is significantly different from the expected value ' 3 ' and hence the Cube Law $W=c L^{n}$ did not hold good in the case of Glossogobius giuris in the river. The correlation co-efficient (r) in Glossogobius giuris was found to be 1, indicating that there is high positive correlation between length and weight in the species. The relative condition factor $(K n=1.523)$ remained greater than 1 for the species indicating their general well being to be good in the river.
\end{abstract}

Keywords: Length-Weight relationship, Condition Factor, Glossogobius giuris, correlation co-efficient, River Singla, Karimganj, Assam.

\section{Introduction}

Fishes are finned, aquatic, cold blooded vertebrates and are said to be "gold" from water as they have a high economic value. They are the staple item in the diet of many peoples and are associated with the life of the people of North East(NE) India from time immemorial. The fish production plays a significant role in the human economy. India has vast potential for development of inland fisheries (Das and Kar, 2011). According to Le Cren (1951), knowledge of the length-weight relationship of a fish is essential, since various important biological aspects, namely, general well being of fish, appearance of first maturity, onset of spawning, etc., can be assessed with the help of condition factor, a derivative of this relationship. As length and weight of fish are among the morphometric characters, they can be used for the purpose of taxonomy and ultimately in fish stock assessment (Shadi et al., 2011). In fisheries science, the condition factor is used in order to compare the 'condition', 'fatness' or well being of fish and it is based on the hypothesis that heavier fish of a given length are in better condition. Condition factor has also been used as an index of growth and feeding intensity (Kar, 2007, 2013; Oribhabor et al., 2011). An extensive research on length-weight relationship of commercial freshwater fishes from different water bodies in India is already reported. The length-weight relationship are useful in the standardization of length type when data are summarized (Froese, 1998).

The length-weight relationship (LWR) of fish is an important fishery management tool because they allow the estimation of the average weight of the fish of a given length group by establishing a mathematical relationship. This study reports the Length-Weight relationship and relative condition factor of Glossogobius giuris collected from the River Singla in Karimganj district of Assam.

River Singla originates from Mizoram hill at a height of $365.21 \mathrm{~m}$ MSL as 'Thing Tlwang Lui'. The inlet of biggest wetland, The River Singla enters to Sone Beel after traversing a meander course of $62.75 \mathrm{~km}$ and joins to river Kushiara at Karimganj through river Kachua after covering a length of about $29.30 \mathrm{~km}$. There have been a number of works on the LWR of Freshwater (FW) fishes in NE India. Some of the significant works are those of Kar,D and Barbhuiya, AH (2011 a); Das, B.K., et al. (2013, 14); Das, S., et al. (2014; 2015 a, b, c); Singh, Ng. R., et al.(2015); Kar et al., (2003, 2005, 2006).

\section{Materials And Methods}

The species were identified by using the key provided by Jayaram (2010) and Talwar and Jhingran (1991); Kar (2007). Individual measurements of fish species pertaining to total length (TL cm) and total weight $(\mathrm{g})$ were done with the help of precision of Vernier Calliper and Digital Sartorious Electronic Balance respectively. The total length (TL) of each fish species were taken from the tip of snout to the longest ray of caudal fin. Fish weight was measured after blot drying. The LWR was established by fitting equation of the form: 


$$
\mathrm{W}=\mathrm{cL}^{\mathrm{n}}
$$

Where, $\mathrm{W}$ is the weight of the fish, ' $\mathrm{L}$ ' its length and ' $c$ ' and ' $\mathrm{n}$ ' are constants. Equation (1) could be expressed in the linear form by using logarithms, as given below:

\section{$\log W=\log c+n \log L$}

The constants ' $c$ ' and ' $n$ ' were obtained empirically by using the formulae, as given below:

$$
\begin{gathered}
\log C=\frac{\sum \log W \times\left(\sum \log L^{2}\right)-\sum \log L \times \sum(\log L \times \log W)}{N\left(\sum \log L^{2}\right)-\left(\sum(\log L)^{2}\right)} \\
n=\frac{\sum \log W-N \log C}{\sum \log L}
\end{gathered}
$$

The Fulton's Condition Factor (K) was computed by using the formula, as given below:

$$
\text { Condition Factor }(K)=\frac{\text { Weight }}{(\text { Length })^{3}} \times 100
$$

\section{Results And Discussion}

The formula correlating L-W of Glossogobius giuris is given bellow:

$$
\log \mathrm{W}=0.43+1.47 \log \mathrm{L}
$$

The ' $n$ ' value of length-weight relationship was found to be 1.47, indicating the allometric pattern of growth in the fish. The computed correlation co-efficient (r) value in Glossogobius giuris was found to be 1, indicating high positive correlation between the length and weight in the species in the river. The general well being of the fishes can be predicted by estimating the relative Condition factor. The Condition factor $\left(\mathrm{K}_{\mathrm{n}}\right)$ of Glossogobius giuris collected from river Singla was found to be 1.523 which is greater than 1. Thus, indicating their general well being to be good.

The relationship between length and weight in the fish of Glossogobius giuris follows the cube law strictly and the weight increase observed was a rate of the cube's length in all the samples collected from spatially and geographically different places characterized by different environmental conditions (Prasad and Ali, 2007). The rate of increase in weight in relation to length was slightly higher in the fish collected from the River $(b=3.00)$; it may be due to ecological factors, particularly high dissolved oxygen concentration, circulation of water and forage organisms to the fish. The length-weight relationship was also in a dynamic pattern with highly significant coefficient of determination. According to Tesch (1971), the length-weight relationship in fishes can be affected by habitat and area besides other factors such as seasonal effect, degree of stomach fullness, gonad maturity, sex, health, preservation techniques and differences in the observed length ranges of the specimens.

\section{Acknowledgement}

The author would like to express deep sense of gratitude and regards to Professor Devashish Kar, Assam University, Silchar for his constant encouragement, suggestions, guidance, help and advice throughout the study period from his wide knowledge and unique experience. The author is thankful to UGC for providing the RGNF. At last but not the least, the author would like to thank HOD, other teaching and non-teaching staff of Dept. of Life Science, Assam University, Silchar for their help and support.

\section{References}

[1]. Das, B. K., Dutta, B., Ng. Romen Singh and Kar, D. Length-Weight Relationship of Labeo calbasu (Hamilton-Buchanan) from Sone Beel the biggest Wetland of Assam, India. Paripex- Indian Journal of Research. Vol. 2, Issue: 10, pp 11-13.

[2]. Das, S., Das, T., Das, B. K. and Kar, D. (2015). Length-Weight Relationship and Condition Factor in Channa punctata of River Manu in Tripura. International Journal of Fisheries and Aquatic Studies (IJFAS). 2 (3): 56-57.

[3]. Das, S.; Das, B.K.; and Kar, D. (2015). Length-Weight Relationship and Relative Condition Factor in Xenentodon cancila of River Mat in Mizoram. International Journal of Biology and Biological Sciences.

[4]. Das, S.; Das,T.; Das, B.K.and Kar, D.(2014). Length-Weight Relationship and Condition Factor in Barilius sacra of River Torsa in West Bengal. International Journal of Scientific Research and Reviews 3(3): pp 65-69.

[5]. Day Francis (1889). The Fauna of British India, Including Ceylon and Burma. Published by the British government in India and printed by Taylor and Francis of London.

[6]. Dey, S.C. (1973). Studies on the Distribution and Taxonomy of the Ichthyofauna of the hill streams of Kamrup Khasi-Garo Regions of Assam with special reference to the Functional morphology of some rheophillic Fishes, D.Sc. Thesis, University of Calcutta (India), xi+299pp

[7]. Dutta Munsi, J.S. and Srivastava, M.P. (1988). Natural History of fishes and Systematics of Fresh Water Fishes of India. Narendra Pub. House, Delhi.

[8]. Jayaram, K.C. First Edition (1999). The Freshwater Fishes of the Indian Region, Narendra Publishing House, Delhi.

[9]. Jayaram, K.C. (2010). The Freshwater Fishes of the Indian Region, Narendra Publishing House, Delhi.

[10]. Jhingran ,V.G. First Edition (1997). Fish Fisheries of India. Hindustan Publishing Corporation (India). Delhi. 
A study on the Length- Weight Relationship and Relative Condition Factor in Glossogobius giuris ..

[11]. Kar, D. (2000). Present status of fish biodiversity in South Assam and Tripura, pp 80-82. In: Ponniah, A.G.; Sarker U.K.; (Eds). Fish Biodiversity of Northeastern India. NBFGR-NATP Publication No 2, Luckhnow: 228pp.

[12]. Kar, D. (2007). Fundamentals of Limnology and Aquaculture Biotechnology. Daya Publishing House, New Delhi, India, pp. xvi + 609.

[13]. Kar, D. and Sen, N. (2007). Systematics list and distribution of fish biodiversity in Mizoram, Tripura and Barak drainage in North East India. Zoos print Journal 22(3): pp 2599-2607.

[14]. Kar, D (2013) Wetlands and Lakes of the World, pp.xxx + 687, Springer (London)., Print ISBN 978-81-322-1022-1; e-Book ISBN: 978-81-322-1923-8.

[15]. Kar, D. (2015). Epizootic Ulcerative Fish Disease Syndrome. (Elsevier, USA) ISBN: 9780128025048.

[16]. Kar,D and Barbhuiya, AH (2011 a) . Length-weight relationship and condition factor in Puntius amphibious (Valenciennes) and Puntius vittatus Day from Barak valley region of Assam. J. Inland Fish. Soc. India., 42(1)..

[17]. Kar, D.; Laskar, BA; and, Nath, D. (2003). Length-weight relationship of Salmostoam phulo phulo (Hamilton-Buchanan) collected from River Karnafuli along Indo-Bangladesh border (in Mizoram). J. Applied Zoological Research : 14 (2) : 188-190.

[18]. Kar, D. and Barbhuiya, MH (2005). Length-weight relationship and relative condition factoring Hilsa(Tenualosa) ilisha (Hamiilton) of Barak drainage of Assam. Indian J. Environment and Ecoplanning : 10(1) : 265-267.

[19]. Kar, D; Laskar, BA; and Nath, D (2006). Length-weight relationship of Neolissochilus hexagonolepis (McClelland) and Garra lissorhynchus (McClelland) from River Jatinga in Cachar district of Assam. Indian J. Fish , 52.(4): 495-496.

[20]. 11. Kar, D.; Laskar, BA; and, Nath, D. (2003). Length-weight relationship of Salmostoam phulo phulo (Hamilton-Buchanan) collected from River Karnafuli along Indo-Bangladesh border (in Mizoram). J. Applied Zoological Research : 14 (2) : 188-190.

[21]. Kar, D. and Barbhuiya, MH (2005). Length-weight relationship and relative condition factoring Hilsa(Tenualosa) ilisha (Hamiilton) of Barak drainage of Assam. Indian J. Environment and Ecoplanning : 10(1) : 265-267.

[22]. Le Cren, C.D. (1951) The Length-Weight Relationship and Seasonal Cycle in Gonad Weight and Condition in Perch, Perca fluviatilis. Journal of Animal Ecology.

[23]. Menon, A.G.K.(1999). Check list--fresh water fishes of India. Edited by the Director, Zoological Survey of India, Calcutta.

[24]. Singh, Ng. R.; Das, B. K. and Kar, D. (2015). Length-Weight Relationship (LWR) of Glossogobius giuris (Hamilton-Buchanan, 1822) of Pumlen Lake Thoubal, Manipur, India. International Journal of Environment and Natural Sciences. 5: 1-5. 